\title{
Disposition Collection Date Time
}

National Cancer Institute

\section{Source}

National Cancer Institute. Disposition Collection Date Time. NCI Thesaurus. Code C83246.

The date and time disposition data was collected. 